\title{
Chapter 4 \\ Preferred Courses of Action for Security as Nuclear Arms Control Changes in the 2020s
}

\author{
Tibor Tóth
}

Before we embark upon projecting preferred courses of action for security into the 2020 s as it is prescribed by the title of this contribution it might be timely to undertake a travel back into the recent past and recall how each of us had perceived ten years ago the prospects of strengthening international security for the 2010s.

For me it was a period of optimistic expectations. As the Executive Secretary at that time of the Comprehensive Nuclear Test-Ban Treaty Organization's Preparatory Commission, I anticipated a series of concrete steps strengthening international security in the years and decade to come. My expectations and the expectations of many other practitioners of nuclear arms control were fueled by the upsurge of interest in nuclear arms control and disarmament as witnessed among others by the 2007 proposals of the 'Four Horsemen of the Nuclear Apocalypse', the 2009 Prague speech of president Obama and an emerging nuclear abolition movement.

A few of the measures projected through these and other initiatives have been delivered like the New Start Treaty or the Treaty on the Prohibition of Nuclear Weapons. Many others have not. As a particular disappointment not just for me, but for many others as well, was that no significant breakthrough happened on the entry into force of the CTBT. Notwithstanding the well-founded expectations a decade ago, the 2010s have not gone down into history as a period of bringing about the necessary number of cooperative security measures embodied in arms control, disarmament and other soft diplomacy tools versus the flare up of competitive security, that is military competition and coercive measures fueled by geopolitical drivers.

The disappointing track record of the decade behind us begs for the question why so few cooperative security measures were put in place? Were those packages of cooperative security promoted merely as part of expectation management? Or was the aggregate sum of the projected measures overly ambitious as president Obama

\footnotetext{
T. Tóth $(\bowtie)$

Comprehensive Nuclear-Test-Ban Treaty Organization, Vienna, Austria

e-mail: ecubator2tb@gmail.com
} 
himself implied in his Prague speech? Or was it just the wrong time for the right measures?

We have to address those questions now instead of a belated 'what went wrong' soul-searching again in ten years time. Or what is worst, we should not embark again upon the ritual of pre-NPT review conference goal setting without understanding why it was not feasible to deliver during the 2010s those cooperative measures so many had considered not just essential, but feasible.

Obviously, in the years to come we will not give up on mitigating international security challenges, as they represent one of the wickedest of the 'wicked problems' eclipsed in their severity only by climate change and global pandemics. At the same time while doing that we should build our mitigation efforts on measuring and modelling of why previous mitigation efforts went wrong and how to deploy future ones successfully. Grounding mitigation in measuring and modelling of both the challenge and the intervention would enable us to look beyond the contradictory trade-offs between cooperative security requirements and competitive security Realpolitik. Combining the three Ms might help to understand better the 'when' question: why cooperative security measures are feasible at certain points in time, but they fail at others?

In order to do all that we need a new conceptual framework as well. In a 2016 article $^{1}$ I sought to apply the conceptual models used to describe market trends to international security. In doing so, I illustrated the historically prevailing state of play in the quantitative and qualitative nuclear arms race as trend indexes in the everchanging mix of competitive and cooperative means of pursuing security between states. Market-trends observation and terminology was applied to make the security trend comparisons more easily intelligible. ${ }^{2}$

Along the lines of that article a proposed new conceptual framework within which we undertake measuring, modelling and mitigation would require departures from prevailing cooperative security assumptions:

- We go beyond the NPT review conference-centric assessment of cooperative security requirements. Going even further, we step out of the boundaries of reiterating the prevailing lists of proposed cooperative security measures.

- We assume (though we do not condone), as a present system-of-systems reality, that the mix of cooperative and competitive security measures is not defined by cooperative security, but - the other way around-driven by competitive security.

- We postulate that competitive security itself seems to follow a cyclical pattern of booms and busts. In each post-bust cycle, security is increasingly left to 'selfregulating' market forces of more and more unconstrained competition.

\footnotetext{
${ }^{1}$ Conflict, cooperation, and the Comprehensive Nuclear-Test Ban Treaty: financial markets as a metaphor for cycles in global security [1].

${ }^{2}$ Terms like cycles of boom and bust; bubbles inflated and burst; market adjustment, crash, panic, crisis, recession and depression; bull and bear markets; secular (couple of decades) and primary (couple of years) timeframe.
} 
- As a result of overinvestment in competitive security accompanied by countercyclical regulatory tools removed through unilateral of coordinated 'deregulation', eventually each cycle ends up with a security market "correction" or "crash".

- It is when the competitive bubble bursts and mainly in the aftermath of the ensuing security "panic" or "recession" that regulatory, cooperative security tools are belatedly embraced. Both the Limited Test-Ban Treaty (LTBT) of 1963 and the Comprehensive Nuclear-Test Ban Treaty (CTBT) of 1996 were put in place as global-security regulations primarily as a result of the bursting of a cyclical competitive-security bubble with near-fatal global consequences during the Cuban missile crisis in 1962 and in the INF crisis of the late 1970s and first half of the 1980s, respectively. In both instances, post-crash a multitude of multilateral and bilateral disarmament, arms-control and non-proliferation agreements were acknowledged as crucial regulatory tools in the wake of 'never again' collective soul-searching.

- We assume however, that after a while security balance is sought again through the 'invisible hand' of deterrence and competition forces. As soon as the new competitive boom picks up again cooperative-security arrangements are eroded, overshadowed and squeezed out by a new recurring cycle of competitive security.

- And last, but not least, we postulate the potential emergence of a 'super bubble': the present competitive security bull market that emerged from the mid-1990s is a long-term (secular) one and it coincides from the late 1990s with recurring crises in the financial, economic and social spheres.

The above conceptual framework is admittedly unconventional to prescribe preferred courses of action for security into the 2020s. It assumes that we can't define the security requirements of the decade in the narrow context of how nuclear arms control changes. Furthermore it suggests that even the unorthodox postulate of cooperative security being defined and driven by the boom and bust cycle dynamics of competitive security, is not sufficient to put our arms around the security requirements of the 2020s.

While addressing mitigation, security policy decision-makers and practitioners will have to monitor not just the cyclical dynamics of a two-decades long competitive security bull market and the need for regulatory counter-cyclical measures before the bubble bursts. They have to measure, model and mitigate an emerging super bubble: the spill-over and reinforcing dynamics of the prevailing crises in the financial, economic and social spheres intermingling with the critical build-up of a security bubble. Even in the darkest days of the Cuban missile crisis or the INF-crisis we had not collectively faced such a super bubble. It was in the 1890s and the 1920s such a cyclical convergence emerged in modern history. In both cases the super bubble did burst with unprecedented consequences.

In a world with still nearly twenty thousand warheads, two hundred thousand warheads worth of plutonium and uranium in military and civilian stocks, two hundred thousand tons of spent fuel scattered around hundreds of nuclear power plants all of us, be it decision-makers, practitioners or observers will have to embrace a new approach to security in the 2020 s, both in concepts and in practice. 


\section{Reference}

1. T. Tóth, Twenty years of the comprehensive nuclear-test-ban treaty. Nonproliferation Rev. 23(34) (2016)

Open Access This chapter is licensed under the terms of the Creative Commons Attribution 4.0 International License (http://creativecommons.org/licenses/by/4.0/), which permits use, sharing, adaptation, distribution and reproduction in any medium or format, as long as you give appropriate credit to the original author(s) and the source, provide a link to the Creative Commons license and indicate if changes were made.

The images or other third party material in this chapter are included in the chapter's Creative Commons license, unless indicated otherwise in a credit line to the material. If material is not included in the chapter's Creative Commons license and your intended use is not permitted by statutory regulation or exceeds the permitted use, you will need to obtain permission directly from the copyright holder.

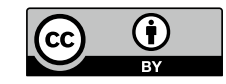

